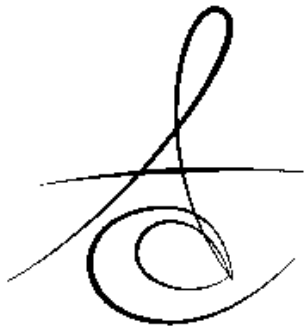

\title{
DEZENFEKTAN KULLANIMININ ELASTOMERİK ÖLÇÜ MATERYALLERİNİN BOYUTSAL STABİLİTESİ ÜZERİNE ETKİSİNİN İN VİTRO OLARAK İNCELENMESİ
}

\section{IN VITRO EVALUATION OF THE EFFECT OF DISINFECTION PROCEDURES ON DIMENSIONAL STABILITY OF ELASTOMERIC IMPRESSION MATERIALS}

\author{
Uzm. Dt. Damla KARA* \\ Dt. Burcu GÜNAL ${ }^{* *}$
}

Makale Kodu/Article code: 3346

Makale Gönderilme tarihi: 10.02.2017

Kabul Tarihi; 18.08.2017

\section{öz}

Amaç: Bu çalışmanın amacı iki farklı sprey dezenfektan kullanımının elastomerik ölçü maddelerinin boyutsal stabilitesi üzerine etkisinin in vitro olarak incelenmesidir.

Gereç ve Yöntem: Çalışmamızda 3 farklı ölçü mad- desi (polieter, kondensasyon tip silikon ve ilave tip silikon) ve iki farklı sprey dezenfektan (Zeta 7: isop- ropanol esaslı ve Descosept: kuarterner amonyum bileşikleri esaslı) kullanıldı. Ölçülerin alınması için pas - lanmaz çelik model kullanıldı ve her bir ölçü madde - sinden 30 adet olacak şekilde, toplam 90 adet ölçü elde edildi . Her bir ölçü maddesi için 10'ar örnek içeren 3 grup oluşturuldu. Zeta 7 ve Descosept sprey uygulanan gruplar 15 dakika bekletildi ve akan su altında yıkandı. Diğer grup ise kontrol grubu olarak kullanıldı. Ölçülere sert alçı dökülerek modeller elde edildi. Hazırlanan alçı modeller üç boyutlu bir dental tarama cihazında taranarak dijital görüntüleri oluşturuldu . Elde edilen dijital model görüntüleri üzerinde cihazın kendi yazılımı kullanılarak referans noktaları arasında lineer ölçümler yapıldı.

Bulgular: Elde edilen verilerin istatistiksel analizi SPSS 22.0 programı kullanılarak yapılmıştır. Verilerin normal dağılıma uyup uymadığı Shapiro-Wilk testi ile kontrol edilmiş ve verilerin normal dağılıma uyması nedeniyle parametrik test kullanılmıştır. İki farklı dezenfektan materyalinin, farklı ölçü materyalleri üzerindeki boyutsal stabilitesine olan etkisinin değerlendirilmesi için independent $t$ testi kullanılmıştır. Sonuçlar $\% 95^{\prime}$ lik güven aralığında değerlendirilmiştir.

Sonuç: Kondanse silikon grubunda her iki kimyasal dezenfektan ajanında boyutsal değişim açısından istatistiksel olarak anlamlı fark gözlemlenmiştir $(p<0,05)$. Polieter ve ilave tip silikon gruplarında her iki kimyasal dezenfektan ajanı uygulaması sonucu boyutsal stabilite açısından istatistiksel olarak anlamlı fark gözlemlenmemiştir $(p<0,05)$.

Anahtar Kelimeler: çapraz enfeksiyon, dezenfektan, ölçü dezenfeksiyonu

\section{ABSTRACT}

Aim: The aim of this study was to determine the effect of spray disinfection procedures on the dimensional stability of elastomeric impression materials.

Material and Methods: In our study, we used 3 different impression materials (polyether, condensation type silicone and additional type silicone) and two different spray disinfectants (Zeta 7: based on isopropanol and Descosept: based on quaternary ammonium compounds). A stainless steel model was used for taking measurements and at each to be 30 , a total of 90 measurements was obtained. For each impression materials, 3 groups of 10 samples were formed. Zeta 7 and Descosept sprayed groups were left for 15 minutes and washed under running water. The other group was used as the control group. Molds were filled with hard gypsum plaster. Dimensional stability were evaluated using a three-dimensional dental scanning device. Linear measurements were made between the reference points on the digital model images using the device's own software.

Results: Statistical analysis was performed using the SPSS 22.0 program. The data was controlled by the Shapiro-Wilk test and parametric test was used because of the normal distribution of the data. Independent $t$ test was used to assess the effect of disinfection procedures on dimensional stability of elastomeric impression materials. The results were evaluated in $95 \%$ confidence interval.

Conclusion: There was statistically significant difference in the mean values of dimensional stability in condensation type silicone $(p<0,05)$. There was no statistically significant difference in the mean values of dimensional stability in polyether and additional type silicone $(p<0,05)$.

Key Words: cross infection, disinfectant, disinfection of impression

\footnotetext{
${ }^{*}$ Adnan Menderes Üniversitesi Diş Hekimliği Fakültesi Protetik Diş Tedavisi AD
}

** Yakın Doğu Üniversitesi Diş Hekimliği Fakültesi Protetik Diş Tedavisi AD 


\section{GİRİ̧̧}

Son yıllarda , bulaşıcı hastalıkların hızı yayılması ve çapraz enfeksiyon riskinin artması nedeniyle, diş hekimliğinde kullanılan materyallerin sterilizasyonu ve dezenfeksiyonu önem kazanmıştır $\quad$. Enfekte tükürüğe ve kana maruz kalan ölçü maddeleri çapraz kontaminasyon için önemli bir kaynaktır. Oral kaviteden gelen mikroorganizmalar ölçü yüzeyinde yaşayabilir ve alçı modellere transfer olabilir. ${ }^{2-6}$

Ölçülerin dezenfeksiyonu diş hekimliğinde rutin bir uygulama olarak değerlendirilmelidir . Ölçüler ve ölçü kaşıkları, ölçü alma işleminden sonra tükürük , kan ve diğer artıkları uzaklaştırmak için akar su altında yıkanmalıdır. Bununla birlikte su ile yıkama ya da akan su altında durulama ölçü yüzeylerindeki kontamine organizmaları tamamıyla uzaklaştırmaz. 4, 7, 8 Ölçüler diğer personele ulaşmadan , alçı model yapımı ve modelle çalışma aşamasından önce zararsız hale gelmelidir. ${ }^{9}$ Bu amaçla klor bileşikleri , sentetik fenolik bileşiklerin karışımı , gluteraldehidler, iyodoforlar ve fenol/alkol kombinasyonları gibi farklı kimyasal dezenfektanlar kullanılabilir. ${ }^{10-13}$ Ölçülerin dezenfeksiyonu için uygulanan metodlar ve ürünler göz önüne alındığında, 2 faktör önemlidir: dezenfeksiyon prosedürlerinin antibakteriyel etkinliği ve bu prosedürlerin ölçü maddelerinin boyutsal stabilitesine etkisi. ${ }^{14}$, 15 Amerikan Diş Hekimleri birliği (American Dental Association-ADA) protetik diş tedavisinde kullanılan , materyal yapısı farklı çok çeşitli tipteki ölçü maddeleri için genel $\mathrm{k}$ aide olarak onaylı bir dezenfektana daldırma veya bu dezenfektanla spreyleme yöntemini tavsiye etmektedir. ${ }^{16}$ Ölçü maddelerinin detay kayde debilme, yüzey pürüzlülüğü , Islanabilirlik ve boyutsal özellikleri kritik yüzey özellikleri olup dezenf ektanların etkileyebildiği yapısal özelliklerdir. ${ }^{17,18}$

Ölçü alma işlemi ， klinik uygulamadan protezlerin yapılacağı laboratuvar aşamalarına geçişi sağlamaktadır. ve ölçü maddelerindeki boyutsal hatalardan ötürü hazırlanacak hareketli vey a sabit protezlerde retansiyon, stabilite ve uyum açısından sorunlar yaşanabilir ; tüm tedavi süreci başarısızlıkla sonuçlanabilir. ${ }^{19,20}$ Bu çalışmanın amacı, sprey dezenfektan kullanımının farklı elastomerik ölçü maddelerinin (polieter, kondensasyon tip silikon ve ilave tip silikon) boyutsal stabilitesi üzerine etkisini in vitro olarak incelemektir.

\section{GEREÇ ve YÖNTEM}

Çalışmamızda 3 farklı ölçü maddesi ve iki farklı sprey dezenfektan kullanıldı. Deney ajanlarının seçimi sırasında kolay bulunabilir olmaları dikkate alındı. Kullanılan ölçü maddeleri : polieter (Impregum penta quick, 3M ESPE, USA), kondensasyon tip silikon (Zetaplus, Zhermack, ITALY) ve ilave tip silikon (Elite $\mathrm{HD}+$, Zhermack, ITALY), sprey dezenfektanlar ise isopropanol esaslı Zeta 7 (Zeta 7 spray, Zhermack, ITALY) ve kuarterner amonyum bileşikleri esaslı Descosept (Descosept AF, Dr. Schumacher, ALMANYA) olarak belirlendi (Tablo I - II). Ölçülerin alınması için üzerinde referans noktaları bulunan ADA 19 no'lu spesifikasyona uygun ölçülerde boyutsal doğruluğunu ve ayrıntıları net olarak verme özelliklerini belirlemek için önerilen paslanmaz çelik model kullanıldı (Resim 1).

Tablo 1.Kullanılan ölçü maddeleri ve özellikleri

\begin{tabular}{|l|l|l|}
\hline Materyal & Materyal Tipi & Üretici Firma \\
\hline Zeta Plus & $\begin{array}{l}\text { Kondanse tip } \\
\text { silikon }\end{array}$ & Zhermack, İTALYA \\
\hline Elite HD + & İlave tip silikon & Zhermack, İTALYA \\
\hline $\begin{array}{l}\text { Impregum } \\
\text { penta quick }\end{array}$ & Polieter & 3M ESPE, AMERİKA \\
\hline
\end{tabular}

Tablo 2. Kullanılan dezenfektan ajanlar ve özellikleri

\begin{tabular}{|l|l|l|}
\hline Dezenfektan & Üretici Firma & İçerik \\
\hline Zeta 7 sprey & $\begin{array}{l}\text { Zhermack, } \\
\text { ITALYA }\end{array}$ & $\begin{array}{l}100 \mathrm{~g} \text { Zeta 7 Sprey: } \\
83 \mathrm{~g} \text { etanol } \\
10 \mathrm{~g} \text { 2-isopropanol }\end{array}$ \\
\hline Descosept AF & $\begin{array}{l}\text { Dr. } \\
\text { Schumacher, } \\
\text { ALMANYA }\end{array}$ & $\begin{array}{l}100 \mathrm{~g} \text { çözelti: } \\
0,05 \mathrm{~g} \text { Etanol, } \\
\text { klorid }\end{array}$ \\
\hline
\end{tabular}

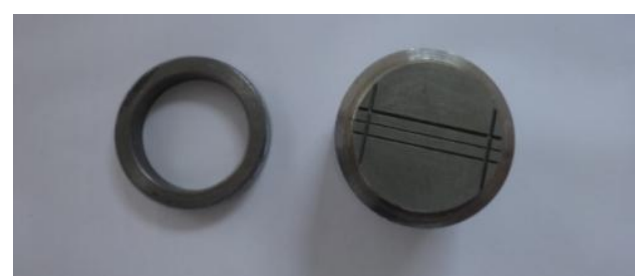

Resim 1. Çalışmada kullanılan paslanmaz çelik model

Paslanmaz çelik model 3 adet yatay çizgiyle kesişen 2 dikey çizgiyle işaretlenmiştir . Her bir ölçü kaydedilmeden önce paslanmaz çelik model etanol ile silindi ve oda sıcaklığında kurumaya bırakıldı Ölçü 
maddeleri firma önerileri doğrultusunda , uygun karıştırma cihazları kullanılarak hazırlandı ve her bir ölçü maddesinden 30 adet olacak şekilde, toplam 90 adet ölçü elde edildi.

Kondanse Silikon Grubu: Yoğun kıvamlı ve akıcı kıvamlı kondanse silikon ölçü maddesinden uygun miktar ve orandaki malzeme el ile çift karıştırma yöntemi ile karıştırıldı. Hazırlanan ölçü maddesi standart olan modeldeki boşluğa yerleştirildi ve üzerine cam ile baskı uygulandı. Ölçü maddesinin sertleşmesini takiben hazır olan örnek metal modelden uzaklaştırıldı (Resim 2). Bu işlem toplam 30 örnek elde edilene kadar tekrarlandı. Elde edilen örneklerin hepsi klinik işlemleri taklit etmek için ilk önce akan suyun altında yıkandı. Rastgele seçilen 10 ar örnekli üç alt grup oluşturuldu ve numaralandırıldı. İlk 10 örnek kontrol grubu olarak ayrıldı ve bu örneklere herhangi bir dezenfektan uygulaması yapılmadı. İkinci 10 örneğe isopropanol esaslı dezenfektan uygulandı ve örnekler 15 dakika boyunca kilitli poşetlerde bekletildi. Sürenin sonunda örnekler tekrar akan suyun altında yıkandı ve hava spreyi kullanarak kalan su uzaklaştırıldı. Üçüncü 10 örneğe kuarterner amonyum bileşikleri esaslı dezenfektan uygulandı ve örnekler 15 dakika boyunca kilitli poşetlerde bekletildi. Sürenin sonunda örnekler tekrar akan suyun altında yıkandı ve hava spreyi kullanarak kalan su uzaklaştırıldı. Örneklere sert alçı (Begostone, Bego, Almanya) dökülerek modeller elde edildi. Hazırlanan bu modeller üç boyutlu bir dental tarama cihazında (Maestro 3D Dental Scaner, Italya) taranarak modellerin üç boyutlu dijital görüntüleri elde edildi (Resim 3). Elde edilen dijital görüntüler kullanılarak modeller üzerindeki referans noktalar (D1D2) arasında lineer ölçümler yapıldı. Paslanmaz çelik model üzerinde D1 noktası sol alt yatay ve dikey çizgilerin kesiştiği dış nokta ile D2 noktası sağ üst yatay ve dikey çizgilerin kesiştiği dış nokta olarak belirlendi.

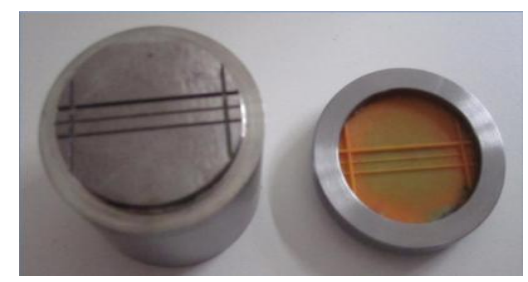

Resim 2. Paslanmaz çelik model üzerinde hazırlanan ölçü maddesi

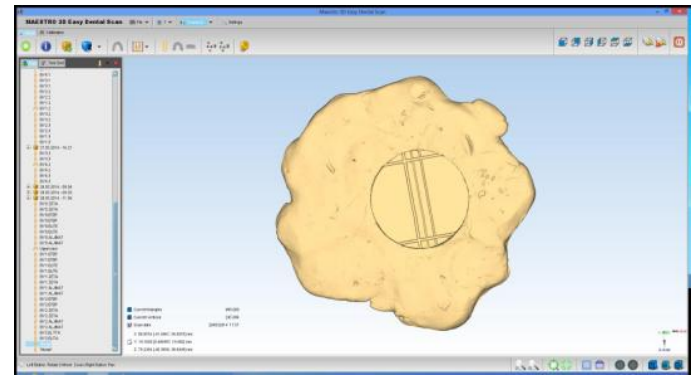

Resim 3. Modellerin taranmasıly elde edilen ve üzerinde ölçümlerin yapıldığı dijital görüntüler.

İlave Tip Silikon Grubu: Kartuş içindeki ilave tip silikon ölçü maddesi kendi otomatik karıştırma cihazına yerleştirilerek karıştırıldı. Hazırlanan ölçü maddesi standart olan modeldeki boşluğa yerleştirildi ve üzerine cam ile baskı uygulandı. Ölçü maddesinin sertleşmesini takiben hazır olan örnek metal modelden uzaklaştırıldı. $\mathrm{Bu}$ işlem toplam 30 örnek elde edilene kadar tekrarlandı. Elde edilen örneklerin hepsi klinik işlemleri taklit etmek için ilk önce akan suyun altında yıkandı. Rastgele seçilen 10 ar örnekli üç alt grup oluşturuldu ve numaralandırıldı. İlk 10 örnek kontrol grubu olarak ayrıldı ve bu örneklere herhangi bir dezenfektan uygulaması yapılmadı. İkinci 10 örneğe isopropanol esaslı dezenfektan uygulandı ve örnekler 15 dakika boyunca kilitli poşetlerde bekletildi. Sürenin sonunda örnekler tekrar akan suyun altında yıkandı ve hava spreyi kullanarak kalan su uzaklaştırıldı. Üçüncü 10 örneğe kuarterner amonyum bileşikleri esaslı dezenfektan uygulandı ve örnekler 15 dakika boyunca kilitli poşetlerde bekletildi. Sürenin sonunda örnekler tekrar akan suyun altında yıkandı ve hava spreyi kullanarak kalan su uzaklaştırıldı. Örneklere sert alçı (Begostone, Bego, Almanya) dökülerek modeller elde edildi. Hazırlanan bu modeller üç boyutlu bir dental tarama cihazında (Maestro 3D Dental Scaner, Italya) taranarak üç boyutlu dijital görüntüleri elde edildi. Elde edilen dijital görüntüler kullanılarak modeller üzerindeki referans noktalar (D1-D2) arasında lineer ölçümler yapıldı. Paslanmaz çelik model üzerinde D1 noktası sol alt yatay ve dikey çizgilerin kesiştiği dış nokta ile D2 noktası sağ üst yatay ve dikey çizgilerin kesiştiği dış nokta olarak belirlendi.

Polieter Grubu: Kartuş içindeki polieter ölçü maddesi maddesi kendi otomatik karıştırma ciha- zına yerleştirilerek karıştırıldı. Hazırlanan ölçü maddesi standart olan modeldeki boşluğa yerleştirildi ve üzerine cam ile baskı uygulandı. Ölçü maddesinin sertleşmesini

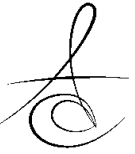


takiben hazır olan örnek metal modelden uzaklaştırıldı. $\mathrm{Bu}$ işlem toplam 30 örnek elde edilene kadar tekrarlandı. Elde edilen örneklerin hepsi klinik işlemleri taklit etmek için ilk önce akan suyun altında yıkandı. Rastgele seçilen 10 ar örnekli üç alt grup oluşturuldu ve numaralandırıldı. İlk 10 örnek kontrol grubu olarak ayrıldı ve bu örneklere herhangi bir dezenfektan uygulaması yapılmadı. İkinci 10 örneğe isopropanol esaslı dezenfektan uygulandı ve örnekler 15 dakika boyunca kilitli poşetlerde bekletildi. sürenin sonunda örnekler tekrar akan suyun altında yıkandı ve hava spreyi kullanarak kalan su uzaklaştırıldı. Üçüncü 10 örneğe kuarterner amonyum bileşikleri esaslı dezenfektan uygulandı ve örnekler 15 dakika boyunca kilitli poşetlerde bekletildi. Sürenin sonunda örnekler tekrar akan suyun altında yıkandı ve hava spreyi kullanarak kalan su uzaklaştırıldı. Örneklere sert alçı (Begostone, Bego, Almanya) dökülerek modeller elde edildi. Hazırlanan bu modeller üç boyutlu bir dental tarama cihazında (Maestro 3D Dental Scaner, Italya) taranarak üç boyutlu dijital görüntüleri elde edildi. Elde edilen dijital görüntüler kullanılarak modeller üzerindeki referans noktalar (D1-D2) arasında lineer ölçümler yapıldı. Paslanmaz çelik model üzerinde D1 noktası sol alt yatay ve dikey çizgilerin kesiştiği dış nokta ile D2 noktası sağ üst yatay ve dikey çizgilerin kesiştiği dış nokta olarak belirlendi.

\section{BULGULAR}

Bulgular Tablo 3 ve Tablo $4^{\prime}$ te verilmiştir. Elde edilen verilerin istatistiksel analizi SPS 22.0 (Statistical Product and Service Solutions, SPSS Inc., Chicago, Amerika) programı kullanılarak yapılmıştır. Verilerin normal dağılıma uyup uymadığı Shapiro-Wilk testi ile kontrol edilmiş ve verilerin normal dağılıma uyması nedeniyle parametrik test kullanılmıştır. İki farklı dezenfektan materyalinin, farklı ölçü materyalleri üzerindeki boyutsal stabilitesine olan etkisinin değerlendirilmesi için independent $t$ testi kullanılmıştır. Sonuçlar \%95'lik güven aralığında $\quad(p<0,05)$ değerlendirilmiştir.

Kondensasyon silikon ölçü materyalinde dezenfektan kullanımı boyutsal stabiliteyi etkilemiş, istatistiksel açıdan anlamlı bir farklılık gözlemlenmiştir $(p=0,004, p=0,033)$. İki farklı dezenfaktanın diğer ölçü materyallerine uygulanması sonucu oluşan boyutsal değerlerde istatistiksel açıdan anlamlı bir farklılık gözlemlenmemiştir.

Tablo 3. Descosept dezenfektan uygulanması sonucu oluşan boyutsal değişim (mm)

\begin{tabular}{|l|l|l|l|}
\hline & $\begin{array}{l}\text { Kontrol } \\
(\boldsymbol{X} \pm \text { SD })\end{array}$ & $\begin{array}{l}\text { Descosept } \\
(\boldsymbol{X} \pm \text { SD })\end{array}$ & $\boldsymbol{p}$ \\
\hline $\begin{array}{l}\text { Polieter } \\
\text { (Impregumpenta } \\
\text { quick) }\end{array}$ & $24.66-0.38$ & $24.67-0.14$ & 0,949 \\
\hline $\begin{array}{l}\text { İlave Tip Silikon } \\
\text { (Elite) }\end{array}$ & $24.69-0.30$ & $24.78-0.14$ & 0.454 \\
\hline $\begin{array}{l}\text { Kondensasyon } \\
\text { Tip Silikon } \\
\text { (Zetaplus) }\end{array}$ & $24.68-0.30$ & $24.13-030$ & $0.004^{*}$ \\
\hline
\end{tabular}

Tablo 4. Zeta Sprey dezenfektan uygulanması sonucu oluşan boyutsal değişim $(\mathrm{mm})$

\begin{tabular}{|l|l|l|l|}
\hline & $\begin{array}{l}\text { Kontrol } \\
(\boldsymbol{X} \pm \text { SD })\end{array}$ & $\begin{array}{l}\text { Zeta sprey } \\
(\boldsymbol{X} \pm \text { SD })\end{array}$ & $\boldsymbol{p}$ \\
\hline $\begin{array}{l}\text { Polieter } \\
\text { (Impregumpenta } \\
\text { quick) }\end{array}$ & $24.66-0.38$ & $24.62-0.22$ & 0,821 \\
\hline $\begin{array}{l}\text { İlave Tip } \\
\text { Silikon(Elite) }\end{array}$ & $24.69-0.30$ & $24.67-0.24$ & 0.888 \\
\hline $\begin{array}{l}\text { Kondensasyon } \\
\text { Tip Silikon } \\
\text { (Zetaplus) }\end{array}$ & $24.68-0.30$ & $24.36-0.26$ & $0.033^{*}$ \\
\hline
\end{tabular}

*İstatistiksel açıdan anlamlı farklıı̆̆ı göstermektedir.

\section{TARTIŞMA}

Hastalardan dental teknisyenlere kadar uzanan çapraz enfeksiyon riski ilgi konusu olan bir konudur. Dental takımdaki bütün kişilerin korunması amacıyla dental ölçüleri de ${ }^{21}$ içeren dental aletlerin dezenfeksiyonu ve yüksek standartlarda hijyeni önerilir. Diş teknisyenlerine yönelik yapılan çalışmalarda Jagger ve ark. ${ }^{22}$ sadece $\% 4$ laboratuvarın dezenfekte edilmiş ölçüler aldığını, buna karşılık \%56'sının gelen ölçü materyallerinin dezenfekte edilip edilmediğini bilmediklerini söylemiştir. Bundan dolayı çoğu laboratuvar (\%94) genellikle ellerine ölçü ulaştığında dezenfekte etmektedir. ${ }^{23}$

Bu çalışmada farklı elastomerik ölçü maddelerinin 2 farklı kimyasal sprey dezenfektan uygulanarak dezenfeksiyonu sonrasında oluşabilecek boyutsal değişimleri araştırılmıştır.

Ölçülerin kimyasal ajanlarla dezenfeksiyonu en güvenilir ve etkili metod olarak görünür. ${ }^{24-28}$ Çalışmamızda bu amaçla klinik ortamlarda kullanılmak üzere piyasada yer alan iki adet kimyasal dezenfektan (Zeta 7 (Zeta 7 spray, Zhermack, Italya, Descosept (Descosept AF, Dr. Schumacher, Almanya) tercih edildi. 
Literatüre bakıldığında ölçü maddelerinin dezenfeksiyonu, ölçü dezenfektan solüsyon içinde bekletilerek ya da sprey şeklinde ölçü yüzeyine sıkılarak yapılmaktadır. Her ne kadar ölçü maddelerinden çapraz enfeksiyon riskini en aza indirmek için dezenfeksiyon yerine ölçüleri su ile yıkamak, debrisi fırça ve deterjan yardımıyla uzaklaştırmak gibi normal hijyenik prosedürlerin yeterli olduğunu savunanlar olsa da; ölçü materyallerinin dezenfeksiyonu zorunlu olmaktadır. ${ }^{29}$ Bu sebepten seçilen ölçü maddesine göre uygulanacak olan dezenfeksiyon yöntemi değişiklik göstermektedir. ${ }^{30}$

Seçilecek dezenfektanın en az orta düzey tüberkülosidal bir dezenfektan olmasına dikkat edilmelidir. ${ }^{31}$ Eğer sprey dezenfektan kullanılacaksa uygulama sonrası ölçüler plastik bir torbada ağzı kapalı bir şekilde önerilen sürede bekletilmelidir. Dezenfektan ile önerilen temas süresi sağlanmalı ve bu işlem çalışma alanında yapılmalıdır; böylece ölçünün taşınması sırasında bir kontaminasyonun da önüne geçilmiş olur. Uygun temas süresinden sonra ölçü maddesi mutlaka akar su altında yıkanmalı, artık dezenfektan yüzeyden uzaklaştırılmalı ve daha sonra alçı model elde edilmelidir. ${ }^{31}$ Boden ve ark. ${ }^{32}$, yaptıkları çalışmada alçının yüzey kalitesinin olumsuz yönde etkilenmesini önlemek amacıyla, dezenfektan uygulanmasını takiben artık dezenfektanın yüzeyden uzaklaştırılması gerektiğini önemle belirtmişlerdir.

Hidrofilik ölçü maddelerinde (polieter) dezenfeksiyon süresinin mutlaka 30 dakikanın altında olması gerektiği bildirilmiştir . Literatürde pek çok çalışmada üretici firmaların önerileri doğrult usunda 60 dakikanın altında temas süreleri test edilmiştir . 24, 33-36 Dezenfeksiyon, sterilizasyona göre daha az öldürücü bir işlem dir. Dezenfeksiyon ile bilinen patojenik mikroorganizmaların neredeyse tamamı elimine edilirken , sporlar gibi tüm mikrobiyal formlar ortadan kaldırılamaz. İnfluenza, enterovirüsler ve tüberküloz basili gibi patojenik mikroorganizmaların vejetatif formlarınının 30 dakika içerisinde öldürülmesinde etkili bir kimyasal ajan kullanılarak dezenfeksiyon sağlanabilir . ${ }^{37}$ Sprey dezenfektanların etkilerini inceleyen çalışmalara baktığımızda 10 dakikalık bekletme süreleri uygulanmıştır. ${ }^{38-39}$ Her ne kadar sprey dezenfektanlar çok daha kısa sürelerde etki gösterse de kuarterner amonyum bileşikleri esaslı dezenfektanın noro virüsler üzerinde de etkili olması amacıyla kullanım talimatları doğrultusunda gerçekleştirdiğimiz çalışmada dezenfektan uygulama süresi 15 dakika olarak tercih edilmiştir.
Sprey dezenfektanlar günümüzde dental piyasada önemli bir yere sahip olarak kimyasal dezenfeksiyonda diş hekimlerinin en büyük yardımcısı olmuştur. Sprey şeklindeki yüzey dezenfektanlarının kullanımlarının kolay ve etkili olmaları, önceden hazırlamayı gerektirmemesi ve pek çok kullanım alanının olması günümüzde yüzeylerin kimyasal dezenfeksiyonunda sıklıkla kullanılmalarını sağlamıştır. ${ }^{40}$

Hepsinde olmasa bile pek çok çalışmada hidrofilik ölçü maddelerinin sprey şeklinde dezenfeksiyonunun daldırma yöntemine oranla daha uygun olduğu bildirilmiştir. Yapılan karşılaştırmalı çalışmalarda daldırma yöntemine göre sprey dezenfeksiyonda daha doğru ve daha stabil modeller elde edildiği gösterilmiştir. ${ }^{24,} 28$, ${ }^{41-43}$ Bizim çalışmamızda da bu görüşe uygun olarak spreyleme metodu tercih edilmiştir.

Hidrofobik ilave silikonlar dezenfeksiyon sonucunda en stabil kalan ölçü maddeleridir . Kısa ve uzun süreli dezenfeksiyon süreçlerinde anlamlı bir farklılık gözlenmemiştir. Hemen hemen tüm dezenfek tanlar ile uyumlu bir şekilde uygulama kolaylığı sağla mıştır. Yüzey pürüzlülüğünün az olması da dezenfek tanın mikrobiyolojik etkinliğine dolaylı katkı sağlamak tadır; çünkü mikroorganizma tutulumu diğer ölçü maddelerine göre daha az olmaktadır. ${ }^{44,45}$

Adabo ve ark. ${ }^{46}$ kondanse tip silikon ölçü mad delerinin \%5.25'lik sodyum hipoklorit çözeltisi içinde 10 dakika bekletilmelerinin boyutsal stabilite üzerinde herhangi bir olumsuz etki yapmadığını bildirmişlerdir . Martin ve ark. ${ }^{47}$ daldırma yöntemiyle Perform-ID dezenfektan uygulanan kondanse tip silikon ölçü materyalinde kontrol grubuna göre boyutsal değişim açısından istatistiksel olarak anlamlı fark gözlemlemişlerdir. Bilgin ve ark. ${ }^{48}$ yapmış oldukları çalışmada kondanse tip silikon ölçü materyalinin sodyum hipoklorit ve mikrodalga enerjisi ile dezenfeksiyonu yapıldığında meydana gelen boyutsal değişimin istatistiksel olarak anlamlı olduğu fakat ilave tip silikonda hiçbir deney ajanında anlamlı boyutsal değişiklik bulunmadığını bildirmişlerdir. Benzer şekilde yaptığımız bu çalışmada da kondanse tip silikon ölçü materyalinde her iki kimyasal dezenfektan grubunda da istatistiksel olarak anlamlı fark bulunmuştur.

Hidrofilik vinil silikon ölçü maddelerinin hipoklorit ve gluteraldehit kullanılarak, immersiyon yöntemi ile dezenfeksiyonu neticesinde dezenfektanın türüne ve uygulama zamanına göre değişiklikler gösteren boyutsal farklılıklar tespit edilmiş ve bu maddelerin immersiyon yöntemi ile dezenfeksiyonu

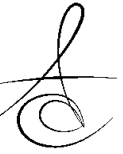


sırasında çok dikkatli olunması gerektiği belirtilmiştir. ${ }^{27}$

Silikon esası ölçü maddelerinin gluteraldehit , sodyum hipoklorit ve povidon iyot ile $30 \mathrm{dk}$ dezenfeksiyon sonucunda ilave silikon ölçü maddelerinin ıslanabilirliğinin kondanse silikon ölçü maddesinden daha iyi olduğu bildirilmiştir. ${ }^{28}$

Dezenfeksiyon sonrası ilave tip silikon ölçü materyalinin uzun dönem boyutsal stabilitesinin incelendiği bir çalışmada, dezenfeksiyon için dual fenol ve sodyum hipokorit $10 \mathrm{dk}$ ve 1 saat süre ile uygulan mıştır ve ölçü maddesinde anlamlı bir boyutsal değişiklik olmadığı bildirilmiştir. ${ }^{49}$ Üç farklı polieter ölçü materyalinin farklı dezenfeksiyon yöntemleri sonu cunda boyutsal stabilitesi değerlendirildiği bir çalış mada, örneklere 10 dakika süre ile sprey dezenfektan, gluteraldehit veya sodyum hipoklorit banyosu uygulanmıştır. Çalışmanın sonucunda, gruplar arasında anlamlı bir doğrusal boyut değişimi görülmediği belirtilmiştir.$^{39}$ Melilli ve ark. ${ }^{50}$ yapmış oldukları çalışmada polieter ve ilave tip silikon ölçü materyallerini daldırma yöntemiyle dezenfekte edilmiş çeşitli zamanlarda boyutsal stabilite açısından ölçümler yapmış ve her iki grupta da istatistiksel olarak anlamlı fark olmadığını bildirmişlerdir. Literatürde yapılan diğer çalışmalara benzer şekilde yaptığımız çalışmada da ilave tip silikon ve polieter öçü materyallerinde her iki tip kimyasal dezenfektan grubunda da boyutsal değişim açısından istatistiksel olarak anlamlı fark bulunamamışır.

Bu çalışmanın limitasyonları arasında; sprey dezenfektanların uygulanmasından sonra belirli zaman aralıklarında ölçüm yapılmaması, ölçü ve dezenfektan materyallerinde daha fazla çeşitlilik sağlanmaması sayılabilir.

Ölçü maddelerinin dekontaminasyonu ile ilgili pek çok çalışma yapılıış bu çalışmalarda tam bir birliktelik sağlanamamışıı, öneriler yeterince detaylandırılmamış ve birbiriyle çelişebilmiştir. Bunun temel sebepleri uygulama şekillerinin; sürelerinin uygulanan dezenfektanların ve çalışmalarda kullanılan ölçü maddelerinin çeşitlilik göstermesi ve deneysel farklııklara bağlı olarak da gerçek bir karşılaştırmanın tam anlamıyla yapılamamasıdır.

Yapılan çalışmalarda ölçü maddelerinin dezenfeksiyonunda ölçü maddeleri üzerinde istatistiksel açıdan anlamlı değişiklikler gözlemleseler de bunların pek çoğunda bu değişikliklerin klinik olarak önemsiz olduğu sonucuna varılıışır. ${ }^{51}$

\section{SONUÇ}

1. Kondanse silikon grubunda her iki kimyasal dezenfektan ajanında da boyutsal değişim açısından istatistiksel olarak anlamlı farklılık gözlemlenmiştir. Bu sebepten isopropanol esaslı (Zeta 7) ve kuarterner amonyum bileşikleri esası ı (Descosept) kimyasal dezenfektanların kondanse silikon ölçü materyallerinde dezenfeksiyonu sırasında dikkatli olunmalıdır.

2. Polieter ve ilave tip silikon gruplarında her iki kimyasal dezenfektan ajanı uygulaması sonucu boyutsal stabilite açısından istatistiksel olarak anlamlı farklılık gözlemlenmemiştir

Damla Kara: ORCID ID: 0000-0002-7853-9634

Burcu Günal: ORCID ID: 0000-0001-5098-1765

\section{KAYNAKLAR}

1. Chau VB, Saunders TR, Pimsler M, Elfring DR. Indepth disinfection of acrylic resins. J Prosthet Dent 1995;74:309-13.

2. Powell GL, Runnels RD, Saxon BA, Whisenant BK. The presence and identification of organisms transmitted to dental laboratories. J Prosthet Dent 1990;64: 235-7.

3. Gerhardt $D E$, Sydiskis RJ Impression materials and virüs. J Am Dent Assoc 1991;122: 51-4.

4. Rice CD, Dykstra MA, Gier RE, Cobb CM. Microbial contamination in four brands of irreversible hydrocolloid impression materials. J Prosthet Dent 1991;65:419-23.

5. Samaranayake LP, Hunjan M, Jennings KJ. Carriage of oral flora on irreversible hydrocolloid and elastomeric impression materials. J Prosthet Dent 1991;65: 244-9.

6. Mitchell DL, Hariri NM, Duncanson MG Jr, Jacobsen $\mathrm{NL}$, McCallum RE. Quantitative study of bacterial colonization of dental casts. J Prosthet Dent 1997;78:518-21.

7. McNeil MR, Coulter WA, Hussey DL. Disinfection of irreversible hydrocolloid impressions: a comprative study. Int J Prosthodont 1992;5:563-7.

8. Beyerle MP, Hensley DM, Bradley DV Jr, Schwartz RS, Hilton TJ. Immersion disinfection of irreversible hydrocolloid impressions with sodium hypochlorite. Part 1: microbiology. Int J Prosthodont 1994; 7:234-8.

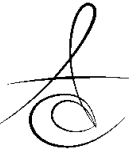


9. Vayısoğlu Özcan A, Nalbant L, Nalbant D. Protetik diş tedavisinde dezenfeksiyon ve sterilizasyon. Atatürk Üniv Diş Hek Fak Derg 2016; 26: 169-79.

10. Vandewalle KS, Charlton DG, Schwartz RS, Reagan $\mathrm{SE}$, Koeppen RG. Immersion disinfection of irreversible hydrocolloid impressions with sodium hypochlorite. Part II: effect on gypsum. Int J Prosthodont 1994;7:315 - 22.

11. Lepe X, Johnson GH, Berg JC. Surface characteristics of polyether and addition silicone impression materials after long term disinfection. J Prosth Dent 1995;74:181-6.

12. Hilton TJ, Schwartz RS, Bradley DV. Immersion disinfection of irreversible hydrocolloid impressions. Part 2: effects on gypsum casts. Int J Prosthodont 1994;7:424-33.

13. Matyas J, Dao N, Caputo AA, Lucatorto FM. Effects of disinfectants on dimensional accuracy of impression materials. J Prosth Dent 1990;64:25 31.

14. Council on Dental Materials, Instruments and Equipment. Disinfection of impression. J Am Dent Assoc 1991;122: 110

15. Kohn WG, Harte JA, Malvitz DM, Collins AS, Cleveland JL, Eklund $\mathrm{KJ}$ Guidelines for infection control in dental health care settings. J Am Dent Assoc 2004;135: 33-47

16. ADA Council on Scientific Affairs and ADA Council on Dental Practice.Infection control recommendations for the dental office and the dental laboratory. J Am Dent Assoc 1996;127:672-80.

17. Owen CP, Goolam G. Disinfection of impression materials to prevent viral cross contamination: a review and a protocol. International J Prosthod 1993;6:480-94.

18. Gerhardt DE, Williams HN. The affecting and stability of sodium hypochlorite solutions used to disinfect dental impressions. Quintessence Int 1991;22:587-91.

19. Sofou A, Larsen $T$, Fiehn N-E, Öwall B. Contamination level of alginate impression arriving at a dental laboratory. Clin Oral Invest 2002;6:161-5.

20. Hisako, Masahiro, Hideharu, Takayuki. Effect of immersion disinfection of alginate impressions in sodium hypochlorite solution on the dimensional changes of stone models Dent Material J 2012; 31: 280-286
21. Council on Dental Materials, Instruments and Equipment, the Council on Dental and Practise, Council on Dental Therapeutic Infection control recommedation fort he dental office and the dental laboratory. J Am Dent Assoc 1988;116:241-8.

22. Jagger DC, Hugget $R$, Harrison A. Cross-infection control in dental laboratories. $\mathrm{Br}$ Dent J 1995;179:93-6.

23. Kugel G, Perry RD, Ferrari $M$, Lalicata $P$. Disinfection and communication practise: asurvey of U.S dental laboratories. J Am Dent Assoc 2000;131:786-92.

24. Kern M, Rathmer R, Strub JR. Three-dimensional investigation of the accuracy of impression materials after disinfection. J Prosthet Dent 1993;70:449-56.

25. Holtan JR, Olin PS, Rudney JD. Dimensional stability of a polyvilylsiloxane impression material following ethylene oxide and steam autoclave sterilization. J Prosthet Dent 1991; 65:519-25.

26. Abdelaziz KM, Hassan AM, Hodges JS. Reproducibility of sterilized rubber impressions. Braz Dent J 2004;15:209-13.

27. Hiraguchi $H$, Uchida $H$, Nakagawa $H$, Tanabe $N$, Habu $\mathrm{H}$. Effects of immersion disinfection of vinyl silicone rubber impressions on reproducibility of stone models. J Dent Mate 1999;18:18-4.

28. Ünlü $A$, Kaya $F$, Öktemer $M$. Investigation of the effect of disinfectant solution on silicone impression materials wettability. Turkiye Klinikleri J Dental Sci 1997; 3: 30-4.

29. Chia WK, Stevens L, Basford KE, Randell DM. Dimensionalchange of impressions on sterilization. Aust Dent J 1990;35:23-6.

30. Kotsiomiti $H$, Totsika A, Diakoyianni-Mordohai $H$, Kaloyiannides $A$. The influence of antiseptic solutions used against AIDS on dental waxes, shellac bases, impression compound and zincoxide eugenol paste. Hell Stomatol Chron 1989;33:149-57.

31. Sofou A, Larsen $T$, Owall B, Fiehn NE. In vitro study of transmission of bacteria from contaminated metal models to stone models via impressions. Clin Oral Investig 2002;6:166-70.

32. Boden J, Likeman P, Clark R. Some effects of disinfecting solutions on the properties of alginate impression material and dental stone. Eur J Prosthodont Restor Dent 2001;9:131-5. 
33. Taylor RL, Wright PS, Maryan C. Disinfection procedures: their effect on the dimensional accuracy and surface quality of irreversible hydrocolloid impression materials and gypsum casts. Dent Mater 2002;18:103-10

34. Johnson GH, Drennon DG, Powel GL. Accuracy of elastomeric impressions disinfected by immersion. J Am Dent Assoc 1988;116: 525-30.

35. Durr DP, Novak EV. Dimensional stability of alginate impressions immersed in disinfecting solutions. ASDC J Dent Child 1987;54:45- 8.

36. al-Omari WM, Jones JC, Wood DJ. The effect of disinfecting alginate and addition cured silicone rubber impression materials on the physical properties of impressions and resultant casts. Eur J Prosthodont Restor Dent 1998;6:103-10.

37. Al-Jabrah O, Al-Shumailan Y, Al-Rashdan $\mathrm{M}$. Antimicrobial effect of 4 disinfectants on alginate, polyether, and polyvinyl siloxane impression materials. Int J Prosthodont. 2007; 20: 299-307.

38. Suprono SM, Kattadiyil TW, Goodacre CJ, Winer MS. Effect of disinfection on irreversible hydrocolloid and alternative impression materials and the resultant gypsum casts. J Prosthet Dent 2012; 108:250-8.

39. Yilmaz H, Aydin C, Gul B, Yilmaz C, Semiz M. Effect of disinfection on the dimensional stability of polyether impression materials. J Prosthodont 2007; 16: 473-9.

40. Kaplan BA, Goldstein GR, Boylan R. Effectiveness of a professional formula disinfectant for irreversible hydrocolloid. J Prosthet Dent 1994;71: 603-6.

41. Drennon DG, Johnson GH, Powell GL. The accuracy and efficacy of disinfection by spray atomization on elastomeric impressions. J Prosthet Dent 1989;62:468-75.

42. Olsson $\mathrm{S}$, Bergman B, Bergman M. Agar impression materials, dimensional stability and surface detail sharpness following treatment with disinfectant solutions. Swed Dent J 1987;11:16977.

43. Tan HK, Hooper PM, Buttar IA, Wolfaardt JF. Effects of disinfecting irreversible hydrocolloid impressions on the resultant gypsum casts: Part II-Dimensional changes. J Prosthet Dent 1993; 70:532-7.
44. Kotsiomiti E, Tzialla A, Hatjivasiliou K Accuracy and stability of impression materials subjected to chemical disinfection - a literature review. J Oral Rehabil 2008;35:291-9.

45. Bock JJ, Fuhrmann RA, Setz J. The influence of different disinfectants on primary impression materials. Ouintessence Int 2008; 39: 93-8.

46. Adabo GL, Zanarotti E, Fonseca RG, Cruz CA. Effect of disinfectant agents on dimensiol stability of elastomeric impression materials. J Prosthet Dent 1999; 81:621-4

47. N. Martina, M.V. Martinb, N.M. Jedynakiewicz The dimensional stability of dental impression materials following immersion in disinfecting solutions dental materials 2007;23:760-8.

48. Bilgin $T$, Kutay Ö, İnce Ö . dezenfeksiyon ve sterilizasyonun silikon esaslı ölçü maddelerinin boyutsal değişimlerine etkileri. İ Ü Diş Hek Fak Derg 1993;27:181-6.

49. Walker MP, Rondeau M, Petrie C, Tasca A, Williams K. Surface quality and long-term dimensional stability of current elastomeric impression materials after disinfection. J Prosthod 2007; 16: 343-51.

50. Melilli D, Rallo A, Cassaro A, Pizzo G. The effect of immersion disinfection procedures on dimensional stability of two elastomeric impresion materials. J Oral Sci 2008;50:441-6.

51. Thouati A, Deveaux $E$, Iost $A$, Behin $P$. Dimensional stability of seven elastomeric impression materials immersed in disinfectants. J Prosthet Dent 1996;76:8-14.

\author{
Yazışma Adresi \\ Uzm. Dt. Damla KARA \\ Adnan Menderes Üniversitesi \\ Diş Hekimliği Fakültesi \\ Protetik Diş Tedavisi AD \\ Girne Mahallesi 2175 Sokak No:5 Kat:1 \\ Aydın \\ e-mail: damlaq_214@hotmail.com
}

